\title{
PENGELOLAAN DANA ZAKAT, INFAQ, DAN SHADAQAH PERSPEKTIF SHARIAH ENTERPRISE THEORY
}

\author{
Sigit Hermawan dan Restu Widya Rini \\ Fakultas Ekonomi Universitas Muhammadiyah Sidoarjo \\ Sidoarjo, Jawa Timur \\ sigithermawan@umsida.ac.id
}

\begin{abstract}
The purpose of this study is to analyze the suitability between reporting information ZIS (Alms, infaq and sadaqah) institutions revealed OPZIS with the concept of Shariah Enterprise Theory. This study uses the method of documentation and interviews to management ZIS (Alms, infaq and sadaqah) is done based on those in item concept Shariah Enterprise Theory by analyzing report on the use ZIS ZIS (Alms, infaq and sadaqah) based on four aspects is god, direct stakeholders, indirect stakeholders and nature. The results of this study indicate that management ZIS (Alms, infaq and sadaqah) in Baznas and Lazismu Sidoarjo there are still deficiencies in conformity with the concept Shariah Enterprise Theory god, direct stakeholders and indirect stakeholders have met with perspective shariah Enterprise Theory but for aspects of nature and the employee has not been done by OPZIS.
\end{abstract}

Keywords : Alms, infaq and sadaqah, Shariah Enterprise Theory

\section{Pendahuluan}

Banyak entitas syariah hanya mengacu pada laba perusahaan yang disajikan dalam laporan keuangan konvensional, dimana didasarkan pada Proprietary dan Entity Theory yang mana hanya terfokus pada laba. Jika Proprietary Theory dan Entity Theory diangggap kurang sesuai dengan tujuan yang dimiliki oleh bisnis Islam, maka yang dianggap mewakili adalah Enterprise Theory karena dalam teori ini suatu entitas tidak hanya berfokus pada laba tapi juga pada stakeholder. Namun Enterprise Theory juga dianggap belum dapat menampung aspek pertanggungjawaban dan ketundukan terhadap syariah. Akhirnya Shariah Enterprise Theory (SET) dianggap lebih dapat mewakili dan dikembangkan pula berdasarkan metafora zakat yang pada dasarnya memiliki karakter keseimbangan (Triyuwono, 2000).

Pada kenyataannya, perusahaan modern pada umumnya berorientasi pada profit dengan menggunakan teori entitas. Tetapi dengan SET, khususnya bagi perusahaan yang berbasis nilai syariah, dapat menggunakan konsep orientasi zakat yang berarti bahwa perusahaan akan berusaha untuk mencapai realisasi zakat yang optimum, ini berarti Net Profit bukan lagi ukuran keberhasilan manajemen perusahaan, tetapi sebaliknya zakat menjadi ukuran kinerja materi dan spiritual.

Beberapa kajian telah dilakukan di bidang akuntansi syariah baik dalam tataran konseptual maupun praktis. Seperti hasil penelitian yang dilakukan oleh Wahid dan Radiah (2010) yaitu menurut survei kuesioner amil zakat bahwa masyarakat muslim masih tidak puas dengan pengelolaan zakat terutama distribusi zakat. Oleh karena itu, menurut argumentasi Slamet (2001) yang pada intinya merekomendasikan Enterprise Theory sebagai konsep teoritis akuntansi syariah karena dianggapnya teori tersebut mengandung nilai keadilan, kebenaran, kejujuran, amanah dan pertanggungjawaban.

Penelitian Othman dan Thani (2010) menyatakan bahwa perusahaan-perusahaan syariah di Malaysia disetujui untuk memulai menyajikan aspek agama untuk laporan keuangan mereka dengan mengungkapkan pelaporan zakat, sedekah dan upah dalam pelaporan sosial Islam. Sementara itu, Sula, dkk (2010) meneliti tentang zakat terhadap aktiva konsepsi, aplikasi dan perlakuan akuntansi yang menawarkan sebuah alternatif untuk penetapan dan perhitungan zakat bagi perusahaan baik dalam tahapan aplikasi atau penerapan di lapangan. Selanjutnya, Nikmatuniayah (2010) meneliti perlunya pelaporan zakat untuk publik yang menawarkan bentuk laporan dana zakat yang telah disesuaikan dengan kaidah-kaidah zakat di perbarui dari Budgeting and Accounting For Disaster Recovery Plan sehingga semua pihak dapat mengawasi dan mengontrol secara langsung pengelolaan dana zakat.

Berdasarkan penelusuran peneliti, masih belum banyak penelitian tentang dana ZIS dalam persektif SET. Penelitian-penelitian yang ada lebih banyak pada aspek pengelolaan ccorporate social responsilibity (CSR) yang dilakukan oleh perbankan syariah dikaitkan dengan perspektif SET, seperti penelitian Mansur (2012) dan Purwitasari (2011). Penelitian tentang pengelolaan dana ZIS dalam 
perspektif SET perlu dilakukan karena akuntansi syariah yang terwujud dalam sebuah laporan tidak saja sebagai bentuk akuntabilitas manajemen terhadap pemilik perusahaan, tetapi juga sebagai akuntabilitas kepada stakeholders dan tuhan. Oleh karena itu, konsep SET diajukan dengan tujuan dapat memberikan dasar dalam pembuatan pelaporan yang berasaskan pada kepentingan stakeholders dibandingkan pada kepentingan stockholders. Dengan kata lain, pelaporan dana ZIS (Zakat, Infaq dan Shadaqah) merupakan praktik yang dibentuk berdasarkan nilai-nilai etika dan norma yang digunakan adalah nilai-nilai agama Islam atau disebut juga dengan nilai-nilai syariah.

Berdasarkan atas dasar argumen dan hasil penelitian diatas, peneliti ingin mengungkapkan analisis kualitatif terhadap penggunaan dana ZIS (Zakat, Infaq, dan Shadaqah) pada OPZIS (Organisasi Pengelola Zakat, Infaq dan Shadaqah) dalam prespektif konsep Shariah Enterprise Theory. Sehingga dapat ditelusuri lebih dalam, bagaimana pelaporan dana ZIS kepada Stakeholders apabila menggunakan prespektif Shariah Enterprise Theory pada lembaga OPZIS. Dengan demikian tujuan penelitian ini adalah untuk menganalisis kesesuaian antara informasi pelaporan dana Zakat, Infaq, dan Shadaqah (ZIS) yang diungkap lembaga OPZIS dengan konsep Shariah Enterprise Theory (SET).

\section{Kajian Literatur dan Pengembangan Hipotesis}

Sesuai dengan tujuan penelitian maka penelitian ini menggunakan Shariah Enterprise Theory (SET) sebagai teori utama. Munculnya SET diawali dengan maraknya enterprises theory (ET) yang lebih cenderung ke arah nilai-nilai kapitalisme. Oleh karena itu, ET perlu dikembangkan lagi agar memiliki bentuk yang lebih dekat dengan syariah. Pengembangan ET dilakukan sedemikian rupa sehingga akhirnya diperoleh bentuk yang dikenal dengan Syari'ah Enterprise Theory (SET) (Triyuwono, 2006).

SET sendiri merupakan suatu hasil teori yang telah di internalisasi dengan nilai-nilai islam yang berusaha memahami bahwa tindakan dasar dalam hubungan manusia dengan alam serta tindakan komunikasi dalam hubungan dengan sesama sebagai objek, terdapat pula tindakan dasar lain terkait dengan hubungan manusia dengan penciptanya. Dalam SET, Allah merupakan sebagai sumber utama, karena Dia adalah pemilik yang tunggal dan mutlak. Karena sumber daya yang dimiliki oleh Stakeholders pada dasarnya adalah amanah dari Allah yang di dalamnya melekat sebuah tanggung jawab untuk menggunakannya dengan cara dan tujuan yang telah ditetapkan oleh Sang Pemberi Amanah. SET mengajukan beberapa konsep terkait dengan pengungkapan pertanggung jawaban sosial sebuah lembaga termasuk pelaporan zakat.

Sementara itu, SET tidak hanya peduli pada kepentingan individu (dalam hal ini pemegang saham), tetapi juga pihak-pihak lainnya. Oleh karena itu, SET memiliki kepedulian yang besar pada stakeholders yang luas, seperti Tuhan, manusia, dan alam. Tuhan merupakan pihak paling tinggi dan menjadi satusatunya tujuan hidup manusia Dengan menempatkan Tuhan sebagai stakeholders tertinggi, maka tali penghubung agar akuntansi syariah tetap bertujuan pada "membangkitkan kesadaran ketuhanan". Bentuk implementasi terhadap Allah dapat dianggap sebagai upaya OPZIS untuk memenuhi prinsip syariah yang dapat dilihat melalui adanya kegiatan- kegiatan yang berkaitan dengan bidang keagamaan.

Kelompok stakeholder kedua dari SET adalah manusia. Dalam hal ini dibedakan menjadi dua kelompok yaitu direct-stakeholders dan indirect-stakeholders. Direct-stakeholders adalah pihak-pihak yang secara langsung memberikan kontribusi pada perusahaan, baik dalam bentuk kontribusi keuangan maupun non keuangan yakni donatur dan karyawan. Karena mereka telah memberikan kontribusi kepada perusahaan, maka mereka mempunyai hak untuk mendapatkan kesejahteraan dari perusahaan. Menurut Meutia (2010), bentuk implementasi terhadap direct stakeholders dapat berupa pembuatan majalah untuk para donatur yang berisikan kinerja keuangan secara transparan dan terbuka berupa laporan hasil pengelolahan dana ZIS dalam satu periode. Sedangkan kontribusi terhadap karyawan dapat berupa ketersediaan layanan kesehatan, pemberlakuan training untuk karyawan dan kesempatan untuk meningkatkan karir. Sementara itu, yang dimaksud dengan indirect-stakeholders adalah pihak-pihak yang sama sekali tidak memberikan kontribusi kepada perusahaan (baik secara keuangan maupun non-keuangan), tetapi secara syari'ah mereka adalah pihak yang memiliki hak untuk mendapatkan kesejahteraan dari perusahaan. Menurut Meutia (2010) bentuk implementasi terhadap indirect-stakeholders dapat berupa pemberdayaan usaha mikro, peningkatan taraf hidup masyarakat, bantuan untuk fakir miskin, bantuan pendidikan dan kesehatan.

Kelompok stakeholder terakhir dari SET adalah alam, yakni pihak yang memberikan kontribusi bagi mati-hidupnya perusahaan 
sebagaimana pihak Tuhan dan manusia.Perusahaan eksis secara fisik karena didirikan di atas bumi, menggunakan energi yang tersebar di alam, memproduksi dengan menggunakan bahan baku dari alam, memberikan jasa kepada pihak lain dengan menggunakan energi yang tersedia di alam, dan lain-lainnya. Namun demikian, alam tidak menghendaki distribusi kesejahteraan dari perusahaan dalam bentuk uang sebagaimana yang diinginkan manusia. Wujud distribusi kesejahteraan berupa kepedulian perusahaan terhadap kelestarian alam dengan contoh melalui program tindakan penghijauan lingkungan atau penanaman kembali, pencegahan pencemaran dengan contoh membantu mensukseskan program pengolahan limbah dengan baik dan benar, serta dapat mengungkapkan tentang kebijakan pembiayaan yang mempertimbangkan isu-isu lingkungan, menyebutkan jumlah pembiayaan yang diberikan kepada usaha-usaha yang berpotensi merusak lingkungan dan alasan memberikan pembiayaan tersebut, dan usaha-usaha untuk meningkatkan kesadaran lingkungan pada pegawai (Meutia, 2010). Dengan demikian, apabila dikelompokkan seperti halnya di atas, pengeluaran biaya-biaya menurut SET seperti yang tertera di Tabel 1. menurut hasil wawancara key informant. Selanjutnya, menganalisis dan membandingkan hasil semua data yang diperoleh berdasarkan konsep SET dengan memenuhi empat aspek kontribusi, yakni kontribusi terhadap Allah SWT, direct stakeholders dan indirect stakeholders, serta alam. Berdasarkan ke empat aspek tersebut peneliti menganalisis apakah OPZIS sudah menggunakan dana ZIS organisasinya sesuai dengan SET.

Fokus penelitian ini adalah untuk menganalisis penggunaan dana ZIS dalam konsep SET yang terbagi dalam empat aspek yakni kontribusi terhadap Allah SWT, direct stakeholders dan indirect stakeholders, serta alam dalam pelaporan organisasinya. Yang dimaksud kontribusi terhadap Allah adalah kontribusi yang mengutamakan dalam bidang keagamaan seperti pembenahan masjid, pemberian mesin genset untuk masjid, pemberian corong masjid, bantuan untuk pelaksanaan tilawatil Qur'an dan memberikan pelatihan tenaga dakwah agar masyarakat semakin termotivasi dalam beribadah. Untuk kontribusi terhadap direct stakeholders adalah kontribusi yang ditujukan terhadap para donatur berupa pembuatan majalah sebagai media untuk menampilkan hasil kinerja keuangan dari laporan pengelolaan dana ZIS. Sedangkan kontribusi terhadap karyawan dapat berupa ketersediaan layanan kesehatan,

Tabel 1

Penggunaan Dana ZIS (Zakat, Infaq, Shadaqah)

Contoh:

Perspektif Shariah Enterprise Theory

\begin{tabular}{|c|c|c|c|}
\hline No & Keterangan Pengeluaran & \multicolumn{2}{|c|}{ Nilai Nominal } \\
\hline 1 & $\begin{array}{l}\text { Kontibusi Kepa da Allah SWT } \\
\text { a. Partisipasi pembuatanmasjid/musholla } \\
\text { b. Sosialisasi tenaga dakwah sosial danlayanan jemput zakat }\end{array}$ & $\begin{array}{l}\text { Rp. } \\
\text { Rp. }\end{array}$ & $\begin{array}{l}\mathrm{xxx}_{\text {, }} \\
\mathrm{xxx}_{2}-\end{array}$ \\
\hline 2 & $\begin{array}{l}\text { Konstibusi Kepada Direct Stakeholders } \\
\text { a. Biaya cetakmajalah } \\
\text { b. Biaya programlayanan kesehatan karyawan } \\
\text { c. Biaya program pelatihankaryawan } \\
\text { d. Biaya programjenjang kanir karyawan }\end{array}$ & $\begin{array}{l}\text { Rp. } \\
\text { Rp. } \\
\text { Rp. } \\
\text { Rp. }\end{array}$ & $\begin{array}{l}\mathrm{xxx}_{,-} \\
\mathrm{xxx}_{,-} \\
\mathrm{xxx}_{,-} \\
\mathrm{xxx}_{2}-\end{array}$ \\
\hline 3 & $\begin{array}{l}\text { Kontribusi Kepada In Direct Stakeholders } \\
\text { a. Biaya pendidikan } \\
\text { b. Biaya hidup } \\
\text { c. Biaya kesehatan } \\
\text { d. Biaya programpemberdayaan ekonomi } \\
\text { e. Biaya partisipasi khitanmassal }\end{array}$ & $\begin{array}{l}\text { Rp. } \\
\text { Rp. } \\
\text { Rp. } \\
\text { Rp. } \\
\text { Rp. }\end{array}$ & $\begin{array}{l}\mathrm{xxx}_{,-} \\
\mathrm{xxx}^{-}- \\
\mathrm{xxx}^{-}- \\
\mathrm{xxx}_{\text {,- }}\end{array}$ \\
\hline 4 & $\begin{array}{l}\text { Kontibusi Kepada Alam } \\
\text { a. Partisipasi programpenghijauan lingkungan } \\
\text { b. Partisipasi programpencegahanpencemaranlingkungan } \\
\text { c. Partisipasi program.Jumat bersih }\end{array}$ & $\begin{array}{l}\text { Rp. } \\
\text { Rp. } \\
\text { Rp. }\end{array}$ & $\begin{array}{l}\mathrm{xxx}_{,-} \\
\mathrm{xxx}_{-}- \\
\mathrm{xxx}_{2}-\end{array}$ \\
\hline
\end{tabular}

\section{Metode Penelitian}

Jenis penelitian ini adalah kualitatif (Cresswell et al, 2007) dengan pendekatan interpretive (Smith and Osborn, 2007). Metode kualitatif interpretif digunakan untuk mengungkapkan tentang pengunaan dan pelaporan dana ZIS pada lembaga syariah berdasarkan SET pemberlakuan pelatihan untuk karyawan dan kesempatan untuk meningkatkan karir. Untuk kontribusi terhadap indirect stakeholders adalah kontribusi yang ditujukan terhadap masyarakat yang merupakan pihak yang sama sekali tidak memberikan kontribusi terhadap organisasi seperti bantuan dana kepada fakir miskin, bantuan kesehatan, pendidikan, 
pemberdayaan usaha mikro dll. Selanjutnya, untuk kontribusi terhadap alam adalah kontribusi bagi mati hidupnya organisasi yang eksis secara fisik karena didirikan diatas bumi dapat berupa, bantuan program penghijauan lingkungan, bantuan program kebersihan lingkungan dan bantuan program pencegahan pencemaran lingkungan.

Penelitian dilakukan pada dua obyek penelitian, yakni pada Badan Amil Zakat (BAZ) Kabupaten Sidoarjo dan Lembaga Amil Zakat Muhammadiyah (LAZISMU) Pimpinan Daerah Muhammadiyah (PDM) Kabupaten Sidoarjo. Alasan pemilihan penellitian ini pada dua obyek penelitian karena didasarkan pada beberapa pertimbangan terkait dengan permasalahan yang berkenaan dengan fokus dan tujuan penelitian. Sementara itu, pemilihan pada BAZ Kabupaten Sidoarjo dikarenakan lembaga ini adalah badan yang dibentuk oleh pemerintah yang secara umum ditugaskan untuk melayani masyarakat, sudah beroperasi lama, dan harus melakukan pelaporan secara baik dan transparan. Selanjutnya, pemilihan lokasi penelitian pada LAZISMU Sidoarjo karena lembaga ini adalah bentukan dari masyarakat yang secara aktif melakukan kegiatan ZIF, menarik dana dari masyarakat dan harus juga melakukan pelaporan keuangan dengan baik dan transparan. Dengan pemilihan lokasi penelitian yang demikian maka penelitian ini dapat dilaksanakan dengan baik sehingga dapat mencapai tujuan penelitian yang sudah ditetapkan.

Pengumpulan data dilakukan dengan kombinasi antara in depth interview, dokumentasi, dan observasi (Sugiyono, 2010). In depth interview dilakukan dengan key informant, yakni Bendahara dan staf keuangan di dua lembaga tersebut. In dept interview dilakukan di kantor dan menggunakan alat bantu wawancara dan alat perekam. Dokumentasi dilakukan dengan mengumpulkan data-data antara lain laporan keuangan, laporan pertanggung jawaban kegiatan, dan laporan penggunaan biaya-biaya lainnya, serta dokumentasi yang relevan dengan tema penelitian. Untuk observasi dilakukan dengan mengunjungi langsung dan melihat proses pencatatan sampai penyusunan laporan keuangan pada kedua lembaga tersebut.

Keabsahan data penelitian ini dilakukan dengan dua uji, yakni uji credibility dan uji transferability (Senton, 2004). Uji credibility dilakukan dengan uji triangulasi sumber dan triangulasi metode. Untuk triangulasi sumber dilakukan dengan cross check hasil wawancara antara bendahara dengan staf keuangan pada waktu yang berbeda. Sementara itu untuk triangulasi metode dilakukan dengan cara cross check antara hasil wawancara dengan dokumentasi dan juga dengan observasi. Dengan cara yang demikian maka kredibilitas atau tingkat kepercayaan penelitian ini sangat tinggi. Selanjutnya untuk uji transferability dilakukan dengan cara peneliti menyusun laporan penelitian dengan cara yang rinci, jelas, lengkap, dan parsimoni. Karena dalam penelitian kualitatif tingkat transferability atau keteralihannya diserahkan pada pembaca atau peneliti lain sejauh mana laporan penelitian tersebut dapat dipahami dan ditransfer ke obyek yang berbeda.

Untuk analisis data dilakukan perpaduan antara analisis data kualitatif dengan analisis data terkait dengan tema penelitian. Untuk analisis data kualitatif dilakukan pada saat pengumpulan data sebagaimana ciri khas dari penelitian kualitatif. Untuk tahapan penelitian mengikuti rekomendasi Miles dan Huberman (1984), yakni data collection, data reduction, daya display, dan conclusion. Sementara itu untuk analisis data terkait dengan tema penelitian dilakukan dengan cara menganalisis laporan sumber dan penggunaan dana ZIS dengan konsep SET. Artinya laporan sumber dan laporan penggunaan dana ZIF dievaluasi berdasarkan empat aspek, yakni kontribusi terhadap Allah SWT, in direct stakeholders, direct stakeholders, dan kontribusi pada alam (Meutia, 2010).

\section{Hasil dan Pembahasan}

Untuk dapat sampai pada hasil penelitian yang sesuai dengan tujuan penelitian, peneliti melakukan berbagai proses penelitian dan analisis data dengan cara menggabungkan antara hasil wawancara, dokumentasi, dan observasi. Demikian pula pada saat penelitian, peneliti mengembangkan diri sebagai instrumen penelitian sebagaimana kekhasan penelitian kualitatif. Pada saat data telah terkumpul maka peneliti melakukan coding dan memfokuskan data yang diperoleh pada tujuan penelitian sehingga ada datadata yang harus dibuang dan tidak terpakai. Selanjutnya peneliti menentukan tema dan topik penelitian yang sama berdasarkan proses coding tersebut. Berikut hasil proses coding dalam bentuk konsep dan tema penelitian yang sama.

\begin{tabular}{|c|c|}
\hline Coding & Tema atau Konsep \\
\hline & Tema atau Konsep Utama \\
\hline A & $\begin{array}{l}\text { Tinjauan Pelaporan Dana ZIS oleh BAZ } \\
\text { Kabupaten Sidoarjo Perspektif } S E T\end{array}$ \\
\hline A. 1 & Kontribusi Verital : Allah SWT \\
\hline A. 2 & Kontribusi Horizontal : Direct Stakeholders \\
\hline A. 3 & Kontribusi Horizontal : In Direct \\
\hline A.4 & Stakeholders \\
\hline & Kontribusi Horizontal : Alam \\
\hline B & Tinjauan Pelaporan Dana \\
\hline & LAZISMU Kabupaten Sidoatjo \\
\hline & Perspektif $S E T$ \\
\hline
\end{tabular}




\section{B.1 Kontribusi Verital : Allah SWT \\ B.2 Kontribusi Horizontal : Direct Stakeholders \\ B.3 Kontribusi Horizontal : In Direct \\ B.4 Stakeholders \\ Kontribusi Horizontal : Alam \\ Sumber: Data Display Hasil Coding dan Data Reduction \\ Data-data dokumentasi yang diperoleh peneliti adalah data laporan hasil ZIS BAZ Kabupaten Sidoarjo Bulan September dan Oktober 2014 dan juga data dari LAZISMU Sidoarjo. Selian itu, peneliti juga mendapatkan data in depth interview dengan para key informant.}

Tabel 2

Laporan Hasil Zakat, Infag, dan Shadagah

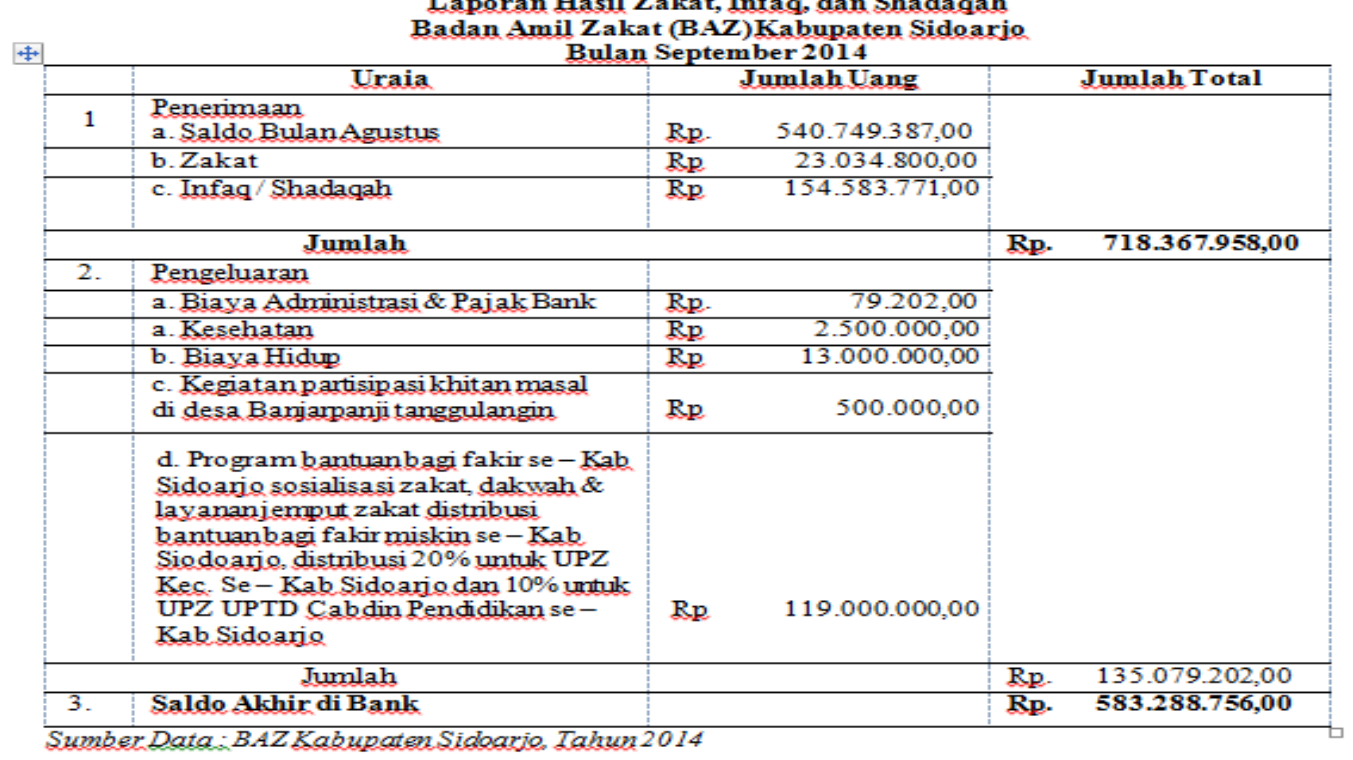

Tabel 3

Laporan Hasil Zakat, Infaq dan Shadaqah Badan Amil Zakat (BAZ)

\begin{tabular}{|c|c|c|c|c|c|}
\hline No & Uraian & & mlah Uang & & Jumlah Total \\
\hline \multirow[t]{3}{*}{1} & $\begin{array}{l}\text { Penerimaan } \\
\text { a. Saldo Bulan September }\end{array}$ & Rp. & $583.288 .756,00$ & & \\
\hline & b. Zakat & Rp & $26.962 .050,00$ & & \\
\hline & c. Infaq / Shadaqah & $\mathrm{Rp}$ & $146.115 .055,00$ & & \\
\hline \multicolumn{4}{|c|}{ Jumlah } & Rp. & $756.365 .861,00$ \\
\hline \multirow[t]{5}{*}{2.} & Pengeluaran & & & & \\
\hline & $\begin{array}{l}\text { a. Biaya Asministrasi \& Pajak Bank } \\
\text { b. Pendidikan }\end{array}$ & $\begin{array}{l}\text { Rp. } \\
\text { Rp. }\end{array}$ & $\begin{array}{r}37.585,00 \\
4.500 .000,00\end{array}$ & & \\
\hline & c. Biaya Hidup & $\mathrm{Rp}$ & $7.000 .000,00$ & & \\
\hline & $\begin{array}{l}\text { d. Partisipasi pemberian santunan bagi } \\
\text { fakir miskin dan keluarga tidak mampu } \\
\text { Kec - Prambon }\end{array}$ & Rp & $2.000 .000,00$ & & \\
\hline & $\begin{array}{l}\text { e. Sosialisasi zakat, dakwah \& layanan } \\
\text { jemput zakat distribusi bantuan bagi fakir } \\
\text { miskin se-Kab Siodoarjo, distribusi } \\
20 \% \text { untuk UPZ Kec. Se - Kab Sidoarjo } \\
\text { dan } 10 \% \text { untuk UPZ UPTD Cabdim } \\
\text { Pendidikan se - Kab Sidoarjo }\end{array}$ & Rp. & $61.795 .000,00$ & & \\
\hline & Jumlah & & & Rp. & $75.332 .585,00$ \\
\hline
\end{tabular}


Tabel 4

Laporan Hasil Pengelolaan Zakat, Infaq dan Shadaqah LAZISMU Pimpinan Daerah Muhammadiyah Sidoarjo

S/D 30 September 2014

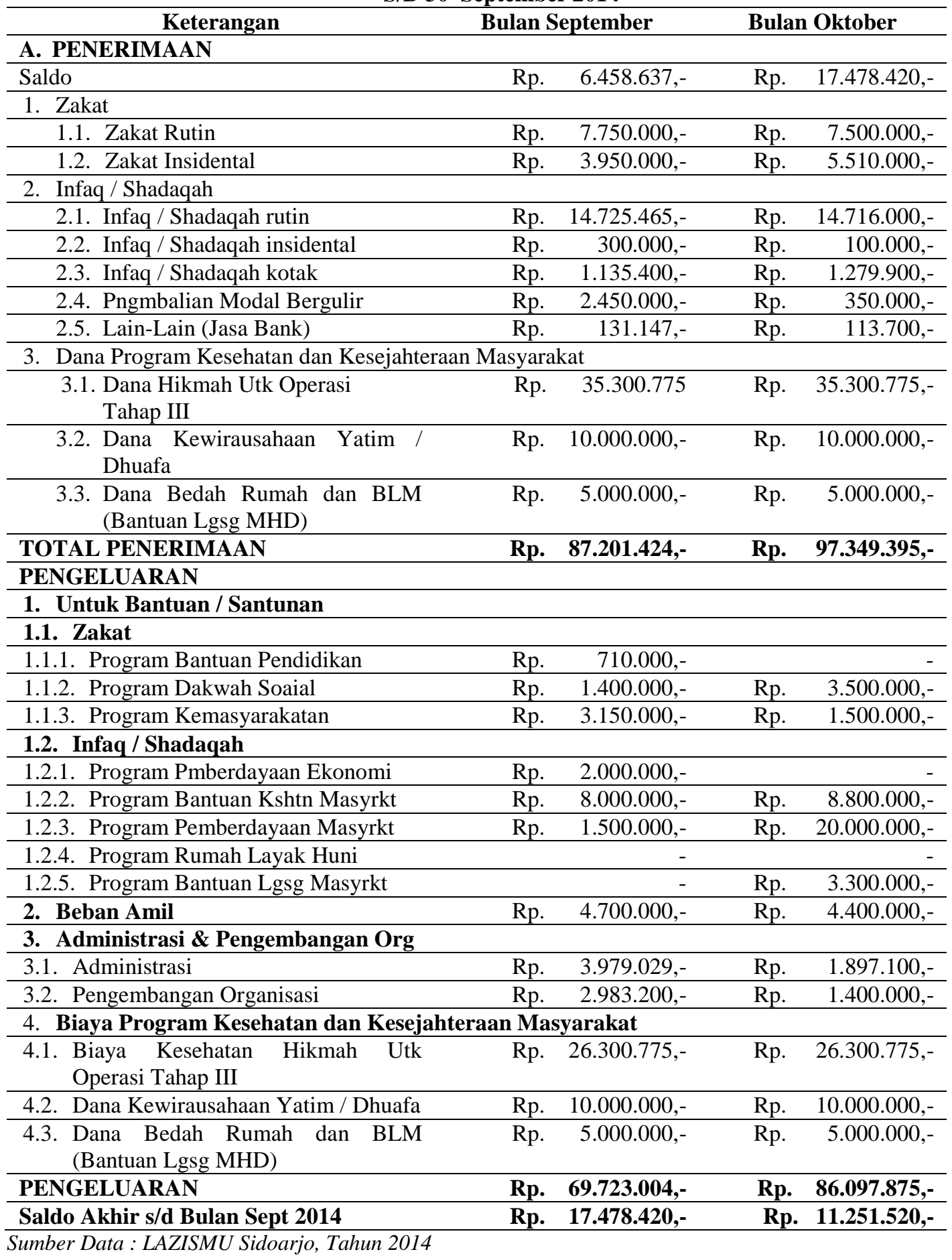


Tabel 5

Laporan Hasil Pengelolaan Zakat, Infaq, dan Shadaqah LAZISMU Pimpinan Daerah Muhammadiyah Sidoarjo S/d Oktober 2014

\begin{tabular}{|c|c|c|c|}
\hline \multirow{2}{*}{$\begin{aligned} & \text { Keterangan } \\
& \text { A. PENERIMAAN } \\
&\end{aligned}$} & Bulan September & \multicolumn{2}{|c|}{ Bulan Oktober } \\
\hline & & & \\
\hline Saldo & 17.478.420,- & Rp. & 11.251.520,- \\
\hline \multicolumn{4}{|l|}{ 1. Zakat } \\
\hline 1.1. Zakat Rutin & $7.500 .000,-$ & Rp. & $5.444 .502,-$ \\
\hline 1.2. Zakat Insidental & $5.510 .000,-$ & Rp. & $1.200 .000,-$ \\
\hline \multicolumn{4}{|l|}{ 2. Infaq / Shadaqah } \\
\hline 2.1. Infaq / Shadaqah rutin & $14.716 .000,-$ & Rp. & 20.025.398,-- \\
\hline 2.2. Infaq / Shadaqah insidental & $100.000,-$ & Rp. & $165.000,-$ \\
\hline 2.3. Infaq / Shadaqah kotak & 1.279.900,-- & Rp. & 1.200.000,- \\
\hline 2.4. Pngmbalian Modal Bergulir & $350.000,-$ & Rp. & $200.000,-$ \\
\hline 2.5. Lain-Lain (Jasa Bank) & $\begin{array}{ll}\text { Rp. } & 113.700,-\end{array}$ & Rp. & $105.453,-$ \\
\hline \multicolumn{4}{|c|}{ 3. Dana Program Kesehatan dan Kesejahteraan Masyarakat } \\
\hline $\begin{array}{l}\text { 3.1. Dana Hikmah Utk Operasi } \\
\text { Tahap III }\end{array}$ & Rp. $\quad 35.300 .775,-$ & Rp. & 26.300.775,- \\
\hline $\begin{array}{l}\text { 3.2. Dana Kewirausahaan Yatim / } \\
\text { Dhuafa }\end{array}$ & 10.000.000,- & Rp. & 10.000.000,- \\
\hline $\begin{array}{l}\text { 3.3. Dana Bedah Rumah dan BLM } \\
\text { (Bantuan Lgsg MHD) }\end{array}$ & $5.000 .000,-$ & Rp. & $5.000 .000,-$ \\
\hline TOTAL PENERIMAAN & 97.349.395,-- & Rp. & 80.892 .748 \\
\hline \multicolumn{4}{|l|}{ PENGELUARAN } \\
\hline \multicolumn{4}{|l|}{ 2. Untuk Bantuan / Santunan } \\
\hline \multicolumn{4}{|l|}{ a. $\quad$ Zakat } \\
\hline i. $\quad$ Program Bantuan Pendidikan & - & Rp. & $1.100 .000,-$ \\
\hline Program Dakwah Soaial & $3.500 .000,-$ & $\mathrm{Rp}$. & 1.100.000,- \\
\hline $\begin{array}{ll}i . & \text { Program Kemasyarakatan } \\
\end{array}$ & $1.500 .000,-$ & Rp. & $1.000 .000,-$ \\
\hline \multicolumn{4}{|l|}{ b. Infaq / Shadaqah } \\
\hline i. $\quad$ Program Pmberdayaan Ekonomi & - & & \\
\hline Program Bantuan Kshtn Masyrkt & $8.800 .000,-$ & Rp. & $500.000,-$ \\
\hline Program Pemberdayaan Masyrkt & $20.000 .000,-$ & Rp. & $2.500 .000,-$ \\
\hline Program Rumah Layak Huni & - & & \\
\hline Program Bantuan Lgsg Masyrkt & $3.300 .000,-$ & & \\
\hline 3. Beban Amil & $4.400 .000,-$ & Rp. & 4.500.000,-- \\
\hline \multicolumn{4}{|l|}{ 4. Administrasi \& Pengembangan Org } \\
\hline a. $\quad$ Administrasi & $1.897 .100,-$ & Rp. & $1.997 .000,-$ \\
\hline b. Pengembangan Organisasi & $\begin{array}{ll}\text { Rp. } & 1.400 .000,- \\
\end{array}$ & Rp. & $283.131,-$ \\
\hline \multicolumn{4}{|c|}{ 5. Biaya Program Kesehatan dan Kesejahteraan Masyarakat } \\
\hline $\begin{array}{llll}\text { a. } & \begin{array}{l}\text { Biaya } \\
\text { Operasi Tahap III }\end{array} & \text { Hikmah Utk } \\
\end{array}$ & Rp. $\quad 26.300 .775,-$ & Rp. & 26.300.775,- \\
\hline b. Dana Kewirausahaan Yatim / Dhuafa & $10.000 .000,-$ & Rp. & 10.000.000,- \\
\hline $\begin{array}{ll}\text { c. Dana Bedah Rumah dan BLM } \\
\text { (Bantuan Lgsg MHD) }\end{array}$ & $5.000 .000,-$ & $\mathrm{Rp}$. & $5.000 .000,-$ \\
\hline PENGELUARAN & 86.097.875,-- & Rp. & 54.180.906,- \\
\hline Saldo Akhir s/d Bulan Sept 2014 & 11.251.520,- & $R p$. & 26.711.842,- \\
\hline
\end{tabular}


Berdasarkan data-data diatas berikutnya peneliti melakukan analisis data yang bersifat kualitatif ataupun analisis data sesuai dengan tema penelitian, yakni membandingkan laporan penggunaan biaya ZIF dengan konsep SET yang direkomendasikan oleh Meutia (2010).

Tinjauan Pelaporan Dana ZIS oleh BAZ Kabupaten Sidoarjo Perspektif Konsep Shariah Enterprise Theory

Sesuai dengan konsep SET yang membagi laporan penggunaan dana ZIF ke dalam empat aspek, yakni kontribusi vertikal kepada Allah SWT, kontribusi horizontal direct stakeholders, kontribusi horizontal in direct stakeholders, dan kontibusi horizontal kepada alam. Berikut penjelasannya.

1. Kontribusi Vertikal : Allah SWT

Pada Laporan Penggunaan Dana ZIS Baznas Kabupaten Sidoarjo bulan September dan Oktober 2014, telah tertera adanya bantuan dalam bentuk keagamaan berupa memberikan sosialisasi, tenaga dakwah dan penyuluhan melalui khutbah hari jumat khususnya daerah terpencil guna kelancaran dalam beribadah kepada Allah SWT yakni untuk bulan September dan Oktober masing - masing sebesar Rp.500.000. Seperti pada kutipan wawancara,

"Untuk kontribusi urusan keagamaan dan yang dimaksud adalah tempat ibadah ya kayak musholah itu memang selama ini di Baz Kab sidoarjo ini diberikan bentuk sarana tapi khususnya di daerah terpencil jadi sarana itu bisa berupa untuk pengeras suara kemudian tandon kemudian bantuan tenaga khotib kemudian bantuan istilahnya yang diperlukan di masjid atau musholah yang ada di daerah terpencil jadi untuk yang tahun ini kita sudah di acc untuk bantuan di daerah tegal sari jabon yang ujung yang terpencil di kalialo kemudian di tlocor juga kemudian di Ketingan untuk yang terpencil tapi untuk bantuan yang berupa fisik itu memang sudah dianggarkan oleh pemerintah melalui bagian kesra itu jadi nantik kita kan melihat bantuan itu biar ndak jumbo sama pihak pemerintah kabupaten yang membantu". (Kutipan wawancara dengan Bpk MN, tanggal 3 Juli 2014)

2. Kontribusi Horizontal : Direct Stakeholders Pada Laporan Penggunaan Dana ZIS

Baznas Kab. Sidoarjo bulan September dan Oktober 2014, berkaitan dengan kontribusi terhadap nasabah atau donatur BAZ memberikan perhatian yang cukup besar, karena salah satu dari nilai-nilai dasar yang diterapkan Baznas Kab. Sidoarjo adalah fokus pada donatur atau nasabah. Hal ini ditunjukkan dengan kinerja keuangan yang transparansi pada Baznas Kab. Sidoarjo selalu mengalami peningkatan. Dari hal ini banyak para pihak yang merasa puas dan jelas akan suatu pelaporan dana ZIS yang dimiliki oleh Baznas Kab. Sidoarjo. Dengan bukti penerimaan baik dari zakat, infaq dan shadaqah maupun jasa bank telah mengalami peningkatan, yakni dari total penerimaan bulan September sebesar Rp. 718.367.958,00 meningkat menjadi Rp. 756.365.861,00 pada total penerimaan bulan Oktober. Dan pada kutipan wawancara,

"Kalau yang namanya majalah kan sudah kita berikan keseluruh donatur baik itu donatur yang sifatnya individu maupun donatur yang sifatnya kelembagaan, untuk biaya cetaknya itu sudah teranggarkan di APBD jadi mereka tinggal menerima saja kita memberikan secara cuma-cuma biasanya kalau lembaga lain itu satu majalah ada yang infaq nya itu Rp. 10.000, Rp. 5.000, Rp. 25.000 tapi kalau di kita itu untuk cetak buletin nya itu di anggarkan di APBD setiap tahun sekali dan buletin itu enam kali cetakan jadi dua bulan sekali kalau untuk APBD nya perkiraan hampir Rp. 60.000.000 setiap tahun untuk biaya cetak sekaligus nara sumber". (Kutipan wawancara dengan Bpk MN, tanggal 24 Pebruari 2015)

Sementara itu, dalam Laporan Penggunaan Dana ZIS Baznas Kabupaten Sidoarjo bulan September dan Oktober 2014, Baznas Kab. Sidoarjo tidak memuat pengeluaran untuk kontribusi terhadap karyawan. Seperti pada hasil wawancara berikut ini.

"Terkait dengan bentuk pengeluaran kontribusi kepada karyawan atau pegawai seperti program layanan kesehatan kemudian program pelatihan kemudian program tunjungan untuk karir , kalau untuk program pelatihan untuk karyawan ini memang setiap tahun ada pelatihan lembaga zakat se jawa timur dan se indonesia satu tahun sekali. Kemudian yang program tunjangan karir ini biasanya kalau memang karyawan itu masih ingin kuliah lagi itu memang sudah kita programkan paling tidak untuk jenjang karir mereka itu sudah kita sediakan. Kalau untuk anggaran kita belum mencanang kan cuma program saja , kalau untuk layanan kesehatan ini masih belum ada”. Jadi untuk kontribusi kepada karyawan, masih belum ada pengeluaran yang dianggarkan tetapi masih dalam bentuk program saja”.(Kutipan wawancara dengan Bpk MN, tanggal 24 Pebruari 2015)

3. Kontribusi Horizontal : Indirect

Stakeholders

Pada Laporan Penggunaan Dana ZIS Baznas 
Kabupaten Sidoarjo bulan September dan Oktober 2014, kepedulian Baznas Kab. Sidoarjo terhadap peningkatan kualitas hidup masyarakat baik dalam bidang pendidikan dan kesehatan dapat dilihat dari program rutinitas dana zakat yang disalurkan, melalui program tersebut Baznas Kabupaten Sidoarjo memberikan bantuan yang bertujuan untuk menciptakan kesejahteraan dalam jangka panjang yakni bisa berupa bantuan biaya pendidikan pada bulan Oktober sebesar Rp. 4.500.000 tetapi untuk bulan September Baznas Kabupaten Sidoarjo tidak melakukan partisipasi untuk biaya pendidikan. Biaya kesehatan bulan September sebesar Rp. 2.500.000 tetapi untuk bulan Oktober Baznas Kabupaten Sidoarjo tidak melakukan partisipasi untuk biaya kesehatan serta untuk biaya hidup bulan September sebesar Rp. 13.000.000 dan Oktober sebesar Rp. 7.000.000. Dalam bentuk kesehatan Baznas Kab. Sidoarjo memberikan dalam bentuk biaya pengobatan seperti memberikan partisipasi pengobatan bagi masyarakat tidak mampu, bentuk biaya pendidikan yakni memberikan sumbangan bantuan untuk siswa yang kurang mampu serta bentuk biaya hidup yakni bagi masyarakat yang kurang mampu. Dan pada hasil wawancara,

"Kemudian untuk yang soal kontribusi kepada masyarakat itu memang sudah hak kita bagi yang mampu untuk membagi bagi yang tidak mampu terutama kalau kita sendiri kan sebagai pengelola yang beada di lembaga zakat ini kan paling tidak membantu sesuai dengan prosedur yang ada”.(Kutipan wawancara dengan Bpk MN tanggal 3 Juli 2014)
2014, Baznas Kabupaten Sidoarjo tidak menunjukkan kontribusi kepada alam. Sekalipun BAZ mengakui bahwa kontribusi lingkungan adalah faktor yang juga penting dalam kelangsungan pekerjaannya. Begitu pula menurut SET, alam adalah salah satu stakeholders yang harus mendapat perhatian dan memiliki hak untuk mendapatkan kesejahteraan. Namun perhatian Baznas Kab. Sidoarjo terhadap alam masih belum terbentuk. Seperti pada kutipan hasil wawancara,

"Kalau untuk bagian alam penghijauan, selama ini kita belum melaksanakan itu ya, belum ada bentuknya karna itu kan sudah dicanangkan oleh pemerintah kabupaten sidoarjo yang mana sudah ada yang menangani oleh pihak seperti itu jadi Baz ndak masuk . Baz masuk itu ketika hal - hal yang tidak ditangani oleh pemerintah itu baru di sela-sela itu Baz masuk sehingga lama-lama itu menjadi program pemerintah yang kayak diawal tahun 2008 kan ada semacam pembinaan bagi mudin lah itu kita laksanakan satu dua kali itu teryata kemudian diambil alih oleh pemerintah kabupaten disela sela itu Baz masuk".(Kutipan wawancara dengan Bpk MN, tanggal 3 Juli 2014)

Dengan demikian berdasarkan data in depth interview dan data dokumentasi, berikut Laporan Penggunaan Dana ZIS BAZ Kabupaten Sidoarjo menurut Perspektif SET (Tabel 6) :

\section{Tabel 6}

Penggunaan Dana ZIS (Zakat, Infaq, Shadaqah) Perspektif Shariah Enterprise Theory

\begin{tabular}{|c|c|c|}
\hline No & $\begin{aligned} \text { Keterangan Pengeluaran } \\
\end{aligned}$ & Nilai Nominal \\
\hline 1 & $\begin{array}{l}\text { Kontibusi Kepada Allah SWT } \\
\text { a. Partisipasi pembangunan masjid / musholla } \\
\text { b.Sosialisasi tenaga dakwah sosial dan layanan jemput zakat } \\
\text { (September } 2014\end{array}$ & Rp. $119.000 .000,-$ \\
\hline 2 & $\begin{array}{l}\text { Konstibusi Kepada Direct Stakeholders } \\
\text { a. Biaya cetak majalah } \\
\text { b. Biaya program layanan kesehatan karyawan } \\
\text { c. Biaya program pelatihan karyawan } \\
\text { d. Biaya program jenjang karir karyawan } \\
\end{array}$ & $\begin{array}{l}- \\
- \\
-\end{array}$ \\
\hline 3 & $\begin{array}{l}\text { Kontribusi Kepada In Direct Stakeholders } \\
\text { a. Biaya pendidikan (Oktober 2014) } \\
\text { b. Biaya hidup (Oktober 2014) } \\
\text { c. Biaya kesehatan (September 2014) } \\
\text { d. Biaya partisipasi khitan massal (September 2014) }\end{array}$ & $\begin{array}{lr}\text { Rp. } & 4.500 .000,- \\
\text { Rp. } & 7.000 .000,- \\
\text { Rp. } & 2.500 .000,- \\
\text { Rp. } & 500.000,-\end{array}$ \\
\hline
\end{tabular}

\section{Sumber Data : Data Diolah (Usulan Penulis)}

4. Kontribusi Horizontal : Alam

Pada Laporan Penggunaan Dana ZIS Baznas

Kabupaten Sidoarjo bulan September dan Oktober
Berdasarkan data-data yang sudah dijelaskan dan juga berdasarkan analisis 
kesesuaian data dengan konsep SET (Meutia, 2010) dapat dijelaskan sebagai berikut :

1. Pengungkapan pelaporan sosial diatas juga sudah mencerminkan tujuan utama yakni akuntabilitas manusia terhadap tuhan. Karena lembaga Baznas Kabupaten Sidoarjo didirikan untuk mengelola zakat, infaq dan shadaqah yang amanah dan profesional. Sebagaimana manusia diberi amanah untuk mengolah sumberdaya dan mendistribusikannya pada seluruh makhluk dimuka bumi ini secara adil.

2. Pengungkapan pelaporan sosial tersebut juga sudah memberikan sarana informasi kepada seluruh stakeholders mengenai seberapa jauh pelaksanaan, pengelolaan, dan pendistribusian dana ZIS yang telah dikelola oleh organisasi Baznas Kabupaten Sidoarjo dengan melampirkan dan membagikan laporan keuangan dana ZIS tersebut dengan melalui sarana media cetak yakni majalah yang disebar kepada seluruh donatur dan masyarakat sehingga para donatur dan masyarakat bisa lebih leluasa dalam memantau perkembangan pengelolaan dan ZIS.

3. Pengungkapan pelaporan sosial tersebut sudah memberikan informasi berbentuk material dan spiritual dalam bentuk pemisahan pengeluaran internal organisasi dan kepentingan umum masyarakat. Dan pelaporan tersebut sudah menunjukkan pengungkapan informasi secara menyeluruh secara kuantitatif tentang penjelasan tambahan mengenai keterangan pihak- pihak yang telah menerima langsung bantuan dari pembagian zakat, infaq dan shadaqah yang ditampilkan dalam pelaporan tersebut.

Tinjauan Pelaporan Dana ZIS oleh LAZISMU Sidoarjo Perspektif Konsep Shariah Enterprise Theory.

Berdasarkan proses analisis data dan cross check antara in depth interview dengan dokumentasi dan observasi diperoleh hasil penelitian sebagai berikut.

1. Kontribusi Vertikal : Allah SWT

Yaitu pada Laporan Penggunaan Dana ZIS Lazismu Sidoarjo bulan Agustus 2014 sebesar Rp. 1.400.000, September sebesar Rp. 3.500 .000 dan Oktober sebesar Rp. 1.000.000 memberikan kontribusi dibidang keagamaan melalui program bantuan tenaga dakwah sosial khususnya bagi fakir miskin guna untuk kelancaran melakukan ibadah semakin mendekatkan diri kepada Allah SWT. Dan dalam hasil wawancara, lazismu juga memberikan kontribusi berupa bantuan pembangunan musholah,

"Untuk kontribusi kepada allah untuk pembangunan masjid kami ada dan itu sering kemarin, bulan januari ada untuk di musholah pangkemiri donasinya sebesar
1.500.000 trus bulan desember ada untuk pembangunan masjid an-nur kendalsewu tarik itu juga 1.500.000". (Kutipan wawancara dengan Sdri $F$, tanggal 16 Pebruari 2014)

2. Kontribusi Horizontal : Direct Stakeholders Yaitu pada Laporan Penggunaan Dana ZIS Lazismu Sidoarjo bulan Agustus, September dan Oktober 2014, dengan memberikan perhatian kepada para nasabah/donatur dalam bentuk kinerja keuangan dengan melaporkan hasil pengelolaan dana ZIS secara terbuka dan transparan dengan tujuan paling utama yakni kepuasan para donatur/nasabah. Dengan bentuk transparansi peningkatan dan penurunan penerimaan baik dalam zakat, infaq dan shadaqah maupun dana lainnya yakni dari penerimaan bulan agustus sebesar Rp. 87.201.424 meningkat menjadi Rp. 97.349.395 pada bulan september ini menunjukkan bahwa donatur/nasabah semakin percaya dan puas akan kinerja keuangan Lazismu. Tetapi untuk bulan oktober mengalami penurunan penerimaan yakni menjadi Rp. 80.892.748. Dan untuk sarana pembagian hasil laporan pengelolaan dana ZIS, pihak lazismu memberikan sarana melalui media cetak berupa majalah. Dalam hasil wawancara,

"Untuk biaya cetak majalah setiap bulan itu kurang lebih Rp. 3.400 .000 itu kalau cetakannya 1200 lembar kalau belum naik sekitar 2.000.000 perbulan.” (Kutipan wawancara dengan Sdri $F$, tanggal 16 Pebruari 2014)

Sementara itu, untuk kontribusi kepada karyawan, pihak LAZISMU tidak memiliki program pengembangan karyawan seperti pada hasil wawancara,

"Untuk karyawan ini kami ya dapat layanan kesehatan mengikuti muhammadiyah kalau dari lazismu sendiri anggarannya tidak ada. Kita bisa berobat ke klinik an nur tanpa mengeluarkan biaya. Untuk pelatihan karyawan ikut PWM tidak mengadakan sendiri jadi kalau kan kita punya jejaring jika jejaring itu mengadakan pelatihan kita mengikuti undangan dari Depag juga. Untuk tunjangan jenjang karier itu tidak ada"(Kutipan wawancara dengan Sdri F, tanggal 16 Pebruari 2014)

3. Kontribusi Horizontal: Indirect Stakeholders Yaitu Dalam Laporan Penggunaan Dana ZIS Lazismu Sidoarjo bulan Agustus, September dan Oktober 2014, dengan memberikan bentuk kontribusi berupa bantuan pendidikan bagi siswa yang kurang mampu dan berprestasi bulan agustus sebesar Rp. 710.000, untuk bulan September tidak melakukan bantuan pendidikan, untuk bulan Oktober sebesar Rp. 1.100.000, pemberdayaan ekonomi bulan agustus sebesar Rp. 2.000 .000 untuk 
bulan September dan Oktober tidak melakukan bantuan pemberdayaan ekonomi, bantuan kesehatan bulan agustus sebesar Rp. 8.000.000, bulan september sebesar Rp. 8.800.000, dan bulan Oktober sebesar Rp. 500.000. Dan pada hasil wawancara,

"Untuk bantuan kepada fakir miskin ada berupa bantuan seperti antuan kesehatan ada bantuan langsung kalau bantuan langsung waktu itu baru pada bulan waktu milad muhammadiyah bulan agustus tiap orang dapat 400.000 itu sekitar 100 orang. Untuk bantuan kesehatan ada dari bulan januari ini ada untuk penderita kanker kami kasih 750.000 untuk operasionalnya saja. Selain itu ada juga untuk operasi penanganan pasian tangan gajah itu sekitar perasinya $4 \mathrm{x}$ biayanya mulai dari 20.000.000, 10.000.000, dan 4.000.000". (Kutipan wawancara dengan Sdri $F$, tanggal 16 Pebruari 2014)
4. Kontribusi Horizontal : Alam

Pada Laporan Penggunaan Dana ZIS Lazismu Sidoarjo bulan Agustus, September dan Oktober 2014, LAZISMU tidak menunjukkan kontribusi kepada alam. Meskipun dalam program lazismu memiliki bentuk berupa program tanggap bencana, tetapi fokus pemberian kontribusi hanya pada para korban bukan pada pelestarian alam. Tetapi pada hasil wawancara,

"Untuk program peduli kepada alam ini, ada kerja sama bersama KKN dalam penanaman mangrove di daerah kalialoh kita bantu Rp. 2.000.000 trus untuk tanggap bencana juga iya penggalangan dana kelud itu kami juga memberikan beberapa pakaian bekas."(Kutipan wawancara dengan Sdri F, tanggal 16 Pebruari 2014)

Dengan demikian berdasarkan data in depth interview dan data dokumentasi, berikut Laporan Penggunaan Dana ZIS LAZISMU Kabupaten Sidoarjo menurut Perspektif SET :

Tabel 7

Penggunaan Dana ZIS (Zakat, Infaq, Shadaqah) Perspektif Shariah Enterprise Theory

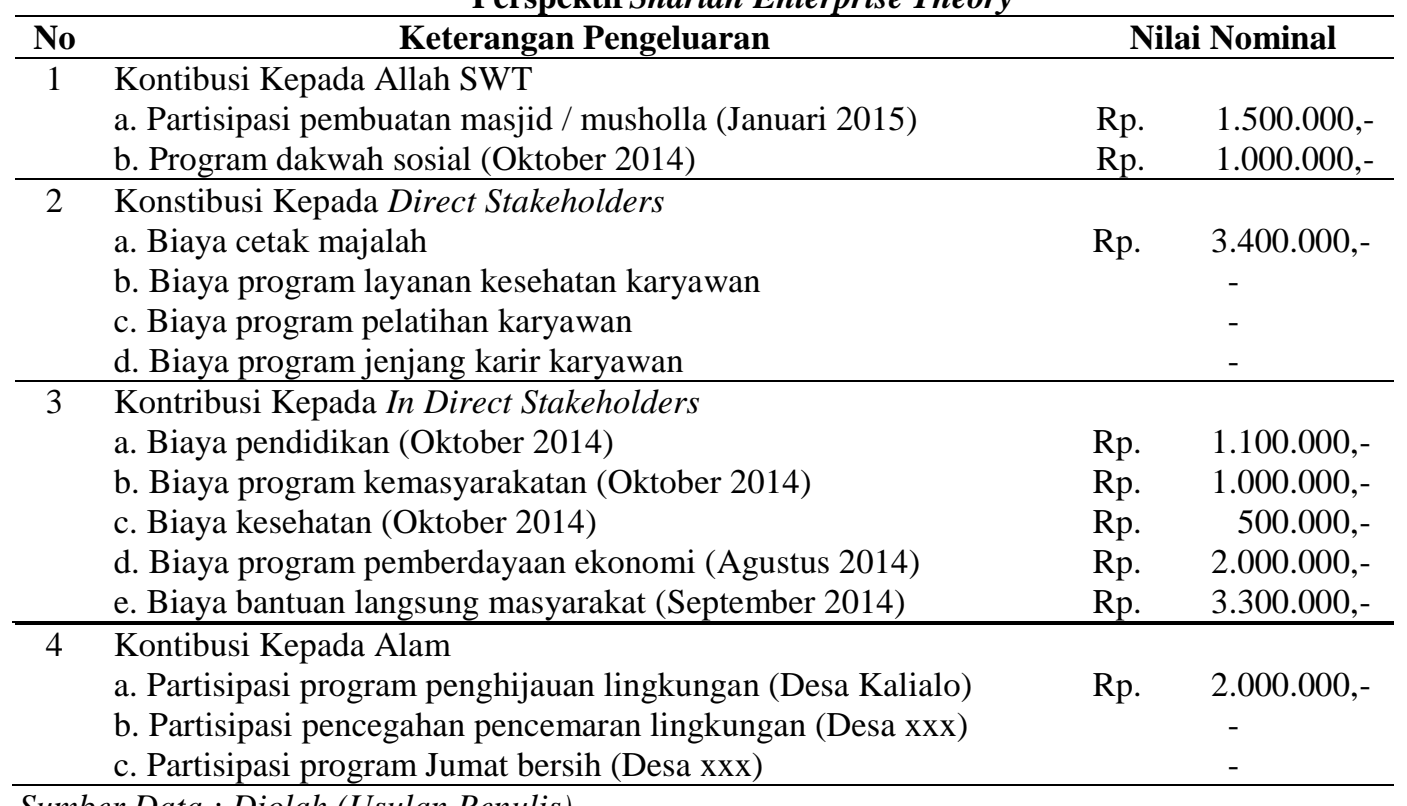


Berdasarkan data-data yang sudah dijelaskan dan juga berdasarkan analisis kesesuaian data dengan konsep SET (Meutia, 2010) dapat dijelaskan sebagai berikut :

1. Pengungkapan pelaporan sosial diatas sudah mencerminkan tujuan utama yakni akuntabilitas manusia terhadap tuhan. Karena pelaporan diatas menunjukkan bahwa stakeholders sebagai manusia diberi amanah untuk mengolah sumberdaya dan mendistribusikannya pada seluruh makhluk dimuka bumi ini secara adil dan lembaga Lazismu telah melaksanakan tugas tersebut yakni sebuah lembaga pengelola dana ZIS yang bersifat terbuka dan berkomitmen untuk disalurkan kepada pihak yang berhak.

2. Pengungkapan pelaporan sosial tersebut sudah memberikan sarana informasi kepada seluruh stakeholders mengenai seberapa jauh pelaksanaan, pengelolaan dan pendistribusian dana ZIS yang telah dikelola oleh organisasi Lazismu dengan melampirkan dan membagikan laporan keuangan dana ZIS tersebut dengan melalui sarana media cetak yakni majalah lazismu yang disebarkan kepada seluruh donatur dan masyarakat.

3. Pengungkapan pelaporan sosial tersebut sudah memberikan informasi berbentuk material dan spiritual dalam bentuk pemisahan pengeluaran internal organisasi dan kepentingan umum masyarakat. Tetapi dalam pelaporan tersebut kurang menunjukkan pengungkapan informasi secara menyeluruh secara kuantitatif tentang penjelasan tambahan mengenai keterangan pihak - pihak yang telah menerima langsung bantuan dari pembagian zakat, infaq dan shadaqah yang tidak ditampilkan dalam pelaporan tersebut.

\section{Simpulan Simpulan \\ Kesimpulan penelitian ini adalah bahwa} untuk pelaporan dana ZIS yang dilakukan oleh Baznas Kabupaten Sidoarjo sebagian sudah sesuai dengan konsep SET, yaitu aspek Allah SWT berupa pembiayaan dakwah sosial, sosialisasi zakat, dan layanan jemput zakat, serta bantuan sarana tempat ibadah. Aspek direct stakeholdersuntuk kontribusi kepada donatur berupa transparansi kinerja keuangan yang dilakukan secara terbuka melalui cetak majalah, aspek indirect stakeholders berupa pembiayaan pendidikan, kesehatan, biaya hidup serta bantuan lainnya kepada masyarakat kurang mampu. Namun terdapat kekurangan yaitu belum terbentuknya program bagian kontribusi terhadap kepedulian lingkungan sekitar atau alam dan untuk kontribusi kepada karyawan Baznas Kabupaten Sidoarjo belum memiliki bentuk pengeluaran tunjangan untuk karyawan.
Sementara itu untuk pelaporan dana ZIS yang dilakukan oleh LAZISMU Sidoarjo sebagian sudah sesuai dengan konsep SET, yaitu aspek Allah SWT berupa pembiayaan dakwah sosial dan bantuan pembangunan tempat ibadah. Untuk aspek direct stakeholders kontribusi kepada donatur berupa transparansi kinerja keuangan yang dilakukan secara terbuka melalui cetak majalah yang dibagikan ke seluruh donatur. Aspek indirect stakeholdersbentuk pengeluaran berupa pembiayaan pendidikan, kesehatan, pemberdayaan ekonomi serta bantuan lainnya kepada fakir miskin. Aspek kepada alam, lembaga lazismu sudah pernah melakukan pengeluaran berupa pembiayaan penanaman tanaman mangrove. Namun pada bagian pengungkapan informasi pada palaporan dana ZIS masih terdapat kekurangan yaitu belum menampilkan informasi secara kuantitatif pada pihak - pihak yang telah menerima bantuan dan untuk kontribusi kepada karyawan lembaga LAZISMU tidak memiliki bentuk program tunjangan untuk karyawan.

\section{Saran}

Saran penelitian ini ditujukan kepada kedua lembaga baik BAZNAS Kabupaten Sidoarjo dan juga LAZISMU Sidoarjo. Saran untuk BAZNAS Sidoarjo bahwa harus lebih banyak menambah program kepedulian lingkungan atau alam dalam program kerja. Dikarenakan sesungguhnya organisasi eksis secara fisik karena didirikan diatas bumi, sehingga sangat perlu bentuk distribusi berupa kepedulian perusahaan terhadap kelestarian alam agar nilai-nilai Islam semakin melekat dalam pengelolaan dana ZIS pada organisasi. Dan menambah program kontribusi tunjangan untuk karyawan karena mereka telah memberikan kontribusi kepada organisasi dan berhak untuk mendapatkan kesejahteraan dari organisasi. Sementara itu saran untuk LAZISMU Sidoarjo adalah untuk menambah program kontribusi tunjangan untuk karyawan karena mereka telah memberikan kontribusi kepada lembaga, maka mereka mempunyai hak untuk mendapatkan kesejahteraan dari lembaga. dalam program kerja pengurus serta menambah informasi secara kuantitatif dalam laporan keuangan untuk lebih memperjelas pihak - pihak yang telah menerima bantuan guna menambah kepercayaan para donatur atau nasabah.

\section{Daftar Pustaka}

[1] Creswell, J. W., W. E. Hanson., V. L. P. Clark., dan A. Morales. 2007. Qualitative Research Designs : Selection and Implementation. The Counseling Psychologist. Vol 35, No 2. March. Pp 236 264.

[2] Mansur, S. 2012. Pelaporan Corporate Social Responsibility Perbankan Syariah 
dalam Perspektif Syariah Enterprise Theory. Skripsi. Jurusan Akuntansi. FEB Universitas Hasanudin. Makassar.

[3] Meutia, I. 2010. Shariah Enterprise Theory Sebagai Dasar Pengungkapan Tanggungjawab Sosial Untuk Bank Syariah. Disertasi. Program Pascasarjana. Universitas Brawijaya. Malang

[4] Miles, M. B., dan A. M. Huberman. 1984. Qualitative Data Analysis. Sage Publication Inc. USA.

[5] Nikmatuniayah. 2010. Perlunya Pelaporan Zakat Untuk Publik. Politeknik Negeri Semarang.

[6] Othman, R., dan A. Thani. 2010. Islamic Social Reporting Of Listed Companies In Malaysia.International Business dan Economics Research Journal. Vol 9 No 4. Universiti Teknologi MARA. Malaysia.

[7] Purwitasari, F. 2011. Analisis Pelaporan Corporate Social Responsilbity Perbankan Syariah dalam Perspektif Shariah Enterprise Theory. Skripsi. FEB. Universitas Diponegoro. Semarang.

[8] Senton, A. K. 2004. Strategies for Ensuring Trustworthiness in Qualitative Research Project. Education for Information 22: 6375.

[9] Shafi, Zurina \& Zainal, Ahmad (Eds). 2013. Post Implementation of Shariah Governance Framework. Malaysia.

[10] Smith, J. A., dan M. Osborn. 2007. Interpretative Phenomenological Analysis. http://med-fom-familymedresearch.sites.olt.ubc.ca/files/2012/03/IPA_ Smith Osborne21632.pdf.

[11] Slamet, M. 2001. Enterprise Theory dalam Konstruksi Akuntansi Syari'ah (Studi Teoritis pada Konsep Akuntansi Syari'ah). Skripsi. Malang: Fakultas Ekonomi Universitas Brawijaya.

[12] Sugiyono. 2010. Metode Penelitian Bisnis. CV. Alfabeta, Bandung.

[13] Sula, Atik Emilia., M. N. Alim., dan R. Zuhdi. 2010. Zakat Terhadap Aktiva Konsepsi Aplikasi dan Perlakuan Akuntansi. Proseding. Simposium Nasional Akuntansi XIII. Purwokerto.

[14] Triyuwono, I. 2006. Perspektif, Metodologi, dan Teori Akuntansi. Penerbit Rajawali Press. Jakarta

[15] - 2000. Organisasi dan Akuntansi Syariah. LkiS. Yogyakarta.

[16] Wahid, H dan A. Radiah. 2010. Localization of Malaysian Zakat Distribution Perceptions of Amil And Zakat Recipients. Malaysia. 